physical education and extracurricular activities. During the study it has been found out that the use of outdoor games directed at patriotic upbringing, which are components of the experimental methodology, will lead to an increase in the level of physical condition and improve moral-volitional qualities of adolescents.

Key words: teenagers, outdoor games, level of physical condition, moral-volitional qualities, patriotic education, experimental technique.

Олена Жадько

Харківський національний педагогічний університет імені Г. С. Сковороди

ORCID ID 0000-0002-1985-1572

DOI 10.24139/2312-5993/2020.01/062-072

\title{
ОРГАНІЗАЦІЯ ВЗАЕМОДІЇ ЗАКЛАДІВ ЗАГАЛЬНОЇ СЕРЕДНЬОЇ ОСВІТИ Й ОРГАНІВ МІСЦЕВОГО САМОВРЯДУВАННЯ В ОСВІТІ ТА ВИХОВАННІ ДІТЕЙ
}

У статmі на основі аналізу наукової літератури й періодичних видань визначено сутність поняття взаємодії органів місцевого самоврядування й закладу загальної середньої освіти (співпраця органів місцевого самоврядування та закладу освіти, школярів і педагогів шляхом координації діяльності, спрямованої на розв'язання спільних проблем, успішну реалізацію їхніх фрункцій $і$ виконання поставлених завдань) та роль місцевого самоврядування у взаємодії із закладами освіти. На основі спостережень, узагальнення досвіду взаємодії органів місцевого самоврядування й закладів освіти розкрито напрями їхньої спільної діяльності.

Ключові слова: взаємодія, органи місцевого самоврядування, заклад загальної середньої освіти, виховання, освіта, діти, організація, напрями.

Постановка проблеми. Для багатьох країн звичною $є$ консолідація зусиль соціуму, громади в питаннях розвитку освіти, що сприяє їх глибинному вивченню та ефективному колективному розв'язанню. Сучасна система освіти передбачає управління з урахуванням громадської думки з метою оптимального поєднання громадських і державних засад в інтересах особистості, влади й суспільства (Волкова, 2014), глибинної інтеграції закладів освіти в навколишнє соціально-економічне середовище, надання їхній діяльності більшої адаптованості й динамічності. Ефективна співпраця закладів освіти й органів місцевого самоврядування сприяє успішному впровадженню суспільних ініціатив, поліпшенню іміджу школи, прискоренню процесу децентралізації та формуванню громадянського суспільства, де громадяни активно долучаються до управління на місцевому, регіональному й загальнодержавному рівнях, залученню додаткових людських і матеріальних ресурсів із метою задоволення потреб та інтересів громади, формування атмосфери взаєморозуміння й довіри між їі представниками (Компонент, 2019; Співпраця, 2017). 
Як свідчить аналіз наукових праць (І. Бех, О. Безпалько, Г. Єльникова, Л. Даниленко, Н. Клокар, О. Марчак, Н. Софій, О. Фоміна) і вивчення масової освітньої практики, успішність виховання громадянина залежить від різних факторів і, зокрема, від того, наскільки ефективно заклад освіти співпрацює 3 органами місцевого самоврядування й, у цілому, соціальним середовищем.

3 огляду на це актуальним $€$ вивчення теоретичних і практичних питань взаємодії закладів загальної середньої освіти з органами місцевого самоврядування.

Аналіз актуальних досліджень. Проблема взаємодії школи й органів місцевого самоврядування певною мірою представлена в дослідженнях сучасних науковців. Так, аналіз проблем виховання молоді та принципи взаємодії соціальних інститутів в освіті розкрито в дослідженнях таких учених, як І. Бех, А. Бойко, О. Вишневський, Л. Гордін, В. Гуров, І. Звєрєва, І. Зязюн, Л. Коваль, І. Кон, І. Лєвшина, В. Москаленко, О. Сухомлинська, С. Хлєбік. Теоретичні та практичні питання взаємодії всіх виховних структур суспільства розглядаються в працях В. Бочарової, П. Вербицької, Б. Вульфова, О. Кривонос, В. Кузя, Л. Новикової, В. Семенова, С. Харченко. Управлінські аспекти взаємодії органів місцевого самоврядування й закладів освіти аналізуються в роботах О. Антонюк, Н. Волкової, В. Грабовського, В. Гурковського, Л. Полішкевич, Н. Рашитової, О. Ярмак. Утім, проблема організації взаємодії закладів загальної середньої освіти й органів місцевого самоврядування в освіті та вихованні дітей не стала предметом цілісного дослідження, що й зумовило цей науковий пошук.

Метою статті є розкриття сутності взаємодії органів місцевого самоврядування й закладу загальної середньої освіти, ролі місцевого самоврядування у взаємодії із закладами освіти та напрямів їхньої спільної діяльності.

Методи дослідження. У статті використано такі методи дослідження: аналіз філософської, соціологічної, політологічної та психолого-педагогічної літератури, періодичних видань для порівняння поглядів науковців на питання взаємодії, розкриття категоріального апарату дослідження; педагогічне спостереження, експертні оцінки для визначення переваг і труднощів взаємодії закладів освіти й органів місцевого самоврядування; вивчення й узагальнення педагогічного досвіду взаємодії закладів загальної середньої освіти та органів місцевого самоврядування для визначення напрямів цієї взаємодії.

Виклад основного матеріалу. Слід зауважити, що в науковій літературі відсутній єдиний погляд на визначення поняття «взаємодія». Воно охоплює всі види діяльності людини (спілкування, пізнання, працю, виховання, навчання тощо) і соціальних процесів і передбачає взаємозв'язок соціальних явищ на рівні соціуму й на рівні функціонування окремих соціальних груп та індивідів (Андрощук, 2013, с. 16). Водночас кожна наука розглядає термін «взаємодія» відповідно до своєї специфіки. 
Так, у філософії взаємодія охоплює процеси впливу різних суб'єктів чи об'єктів один на одного, їхню взаємозміну та взаємозумовленість. Вона виявляється в організації спільних дій, спрямованих на досягнення спільної цілі й реалізацію спільної діяльності (Кожушко, 2013).

Як управлінське поняття «взаємодія» позначає форму зв'язку елементів єдиної системи, за допомогою якої вони доповнюють один одного та створюють умови для функціонування всієї системи (Теорія, 2007). Завдяки їй стає можливим контроль діяльності влади з боку громадськості, пошук консенсусу у відносинах, використовуючи для цього різні механізми й форми (Полішкевич, 2016, с. 283).

В економічній науці взаємодія $\epsilon$ способом, за допомогою якого партнери узгоджують свою мету, завдання й засоби їх досягнення. Взаємодії не може бути там, де немає спільного інтересу та взаємовигідних відносин (Компонент, 2019).

Соціологія вивчає соціальну взаємодію людини та соціуму, їхній вплив і залежність (Ярмак, 2006). Вона включає інтегрованість дій, функціональну координацію наслідків взаємодії та постає системою дій, яка обумовлює засоби реалізації спільної діяльності (Ярмак, 2006, с. 4748). Соціальна взаємодія - форма соціальних зв'язків, що реалізуються в обміні досвідом, інформацією, уміннями, а також у взаємному впливові людей та соціальних спільнот (Дворецька, 2002).

Розрізняють декілька форм взаємодії: конкуренцію, кооперацію, суперництво. Конкуренція позначає нормативно регульований соціальний процес, у якому групи або особи прямують до спільної мети, а її досягнення одними вилучає інших. Конкуренція - це особливий тип боротьби, морально та юридично визнаної соціумом, а її завданням є отримання певного зиску, прибутку, доступу до дефіцитних цінностей (престижу, грошей, популярності, влади). Кооперація означає взаємодію осіб або груп, що об'єднані розв'язанням спільних завдань. Вона передбачає поділ праці й виникає там і тоді, коли явною $є$ перевага об'єднаних зусиль над індивідуальними. Суперництво передбачає боротьбу за суспільне визнання особистих якостей і досягнень (Дворецька, 2002).

У психології взаємодія розглядається як процес опосередкованого або безпосереднього впливу суб'єктів чи об'єктів один на одного, що спричиняє їх взаємозв'язок і взаємообумовленість (Психология, 1990, с. 51). Якщо у процесі взаємодії з'являється протиріччя, воно стає джерелом саморозвитку й саморуху структур (Психология, 1990, с. 51-52). Психологи часто пов'язують взаємодію зі спілкуванням, ототожнюючи їх (А. Бодалєв, Н. Дежнікова), або розглядаючи взаємодію як характеристику спілкування (С. Кудрявцев, М. Лісіна), або визначаючи спілкування як форму взаємодії суб'єктів (Г. Андрєєва, Н. Богомолова, Л. Петровська, О. Леонтьєв, Б. Ломов). 
у педагогічній психології під взаємодією розуміються взаємозбагачення та взаємообмін ії суб'єктів досвідом, установками, змістом діяльності, емоціями (Зимняя, 1997).

Сучасна педагогічна наука часто використовує поняття «педагогічна взаємодія» та розглядає їі крізь призму спільної діяльності та спілкування між педагогом і учнем (Грішко, 2015). У свою чергу, Л. Ковальчук визначає педагогічну взаємодію як систему синергетичної взаємодії всіх суб'єктів педагогічного процесу, що розгортається на рівні діяльнісних підсистем і орієнтується на виховання, навчання й розвиток особистості (Ковальчук, 2005, с. 21). Педагогічна взаємодія передбачає організацію спілкування, взаємодопомогу, спільну працю, обмін інформацією між суб'єктами взаємодії, співпереживання та співучасть у розв'язанні проблем і завдань (Коротаева, 2007).

Поняття «взаємодія» тісно пов'язане з терміном «співробітництво», яке означає командну співпрацю над спільною справою. Водночас, взаємодія передбачає реалізацію прийнятого рішення, коли наявні спільні або довгострокові інтереси (Муркович, 2011).

у вузькому розумінні поняття «взаємодія» схоже 3 поняттям «координація» та розглядається як взаємозалежна, погоджена, діяльність різних суб'єктів. Утім, між цими термінами все жє відмінність. Координація функція одного із суб'єктів системи й містить елемент підкорення координуючому органу системи, який спрямовує діяльність на виконання поставлених завдань (Ярмак, 2006). У свою чергу, взаємодія розглядається як засіб вільних контактів між суб'єктами однієї чи декількох систем.

О. Садова ототожнює поняття «взаємодія» та «партнерство» (Садова, 2016), позначаючи ними об'єднання зусиль окремих осіб або організацій із метою розв'язання нагальних проблем або досягнення значущої мети. Таке партнерство сприяє самоорганізації закладу загальної середньої освіти, обміну ресурсами, суспільним досвідом учасників освітнього процесу, формуванню успішного освітнього середовища для інтелектуального, фізичного, духовного й соціального розвитку особистості, забезпеченню використання освітнього середовища в інтересах громади, соціально-культурному розвитку регіону, залученню громадян до місцевого самоврядування (Садова, 2016, с. 61).

Водночас слід підкреслити важливість співпраці місцевої влади, місцевих відомств і закладів освіти над розв'язанням спільних освітніх завдань, створенням і реалізацією програм і проєктів, спрямованих на покращення освітніх послуг та якості освіти, створенням сприятливих умов для фізичного, психічного й духовного розвитку кожного члена громади.

Існує багато різних способів організації взаємодії закладу освіти з місцевою громадою. Важко знайти громаду, у якій тією чи іншою мірою не перетиналися $б$ інтереси школи, представників місцевої влади, 
громадськості. Уміння поставити спільні цілі й визначити ступінь участі кожного суб'єкта в спільній діяльності $€$ визначальними на початковому етапі взаємодії. Правильний розвиток таких взаємин сприятиме результативній і довгостроковій співпраці в майбутньому. Для цього суб'єкти взаємодії повинні володіти інформацією про специфіку, правові засади та проблеми кожного із суб'єктів, уміти здобувати та працювати з такою інформацією. Створення детального плану спільної діяльності - обов'язкова умова співпраці.

Необхідно зазначити, що місцеве самоврядування $\epsilon$ формою залучення громадян до участі в управлінні своїми справами, а отже, воно $є$ засобом реалізації демократії на місцевому рівні, підвищення добробуту громадян. Первинним джерелом системи місцевого самоврядування визнається територіальна громада, яка здійснює самоврядування в порядку, установленому законом безпосередньо й через представників і виконавчі органи місцевого самоврядування. Тому застосування різних засобів залучення учнівської молоді й учителів до розв'язання питань місцевого значення $є$ надзвичайно важливим для розвитку самоврядування.

Соціальна інфраструктура місцевої громади й закладу освіти має функціонально взаємодіяти 3 органами місцевого самоврядування. Головна мета цієї взаємодії - надання учнівській молоді й педагогам більших можливостей шляхом їх активної участі в громадському, економічному й соціально-побутовому житті громади. Така взаємодія передбачає створення взаємовигідних стосунків між закладом освіти, учнями, педагогами, членами громади та спонсорами для спільного розв'язання проблем. Вона включає розвиток у закладах освіти та громаді традицій і практики громадянської активності, спрямованість ресурсів закладу освіти на розвиток громади, громадянської самоорганізації та самоврядування.

Взаємодія місцевого самоврядування із закладами освіти повинна мати системний, плановий і довгостроковий характер і будуватися на принципах (Компонент, 2019; Полішкевич, 2016): партнерської рівності (переговорний спосіб урегулювання суперечок між сторонами), громадської участі (урахування інтересів усіх учасників і сторін у процесі прийняття рішень), прозорості (надання інформації про всі напрями й результати взаємодії), відкритості (збільшення доступності влади), варіативності (багатогранність і допустимість змін соціальних взаємодій між учнями й місцевим самоврядуванням), поєднаності (наявність ірраціональних соціальних взаємодій при об'єднанні розрізнених автономних властивостей і мотивів у єдину цілісність), різноспрямованої активності (можливість багатоваріантності засобів, форм, методів і шляхів взаємодії органів місцевого самоврядування і закладів загальної середньої освіти), гуманістичної та біоекоетичної спрямованості 
(ставлення до людини як частини природи, безумовної цінності, єдність людських моральних і духовних цінностей із глибоко поважним ставленням до навколишнього природного середовища), сфокусованості на проблемах місцевого розвитку, системності й постійності, чесності, взаємної вигоди, волонтерства, двостороннього спілкування.

Одним із механізмів взаємодії закладів освіти, органів місцевого самоврядування та громадськості, загалом, є соціальне проєктування, яке передбачає їх участь у прийнятті управлінських рішень завдяки створенню й функціонуванню консультативно-дорадчих органів при органах місцевого самоврядування (Кривонос, 2019; Левчук, 2008, с. 5). Учнівська молодь і педагоги мають право користуватися всіма джерелами та інструментами, які впливають на прийняття рішень щодо їхнього статусу й повсякденного життя на місцевому й регіональному рівнях. На рівні місцевої громади учні беруть участь у суспільно-корисній діяльності, що базується на соціальному партнерстві 3 органами місцевого самоврядування та громадськістю (Вербицька, 2010, с. 23).

Роль органів місцевого самоврядування у взаємодії із закладами загальної середньої освіти полягає в реалізації таких напрямів діяльності, як (Антонюк, 2006; Волкова, 2014; Гурковський, 2010; Рашитова, 2010):

- сприяння реалізації державної освітньої політики; налагодження спільної діяльності із центральними органами державної влади та співпраці на міжнародному рівні; сприяння інтеграції української системи освіти у світову;

- формування регіональної наукової політики; сприяння розвитку інтелектуального, освітнього, науково-технічного потенціалу громадян, ураховуючи місцеві національно-культурні та соціально-економічні чинники;

- здійснення моніторингу наукової, науково-технічної та інноваційної діяльності закладу освіти;

- контроль за виконанням закладами освіти державних вимог щодо рівня, змісту й обсягу надання освітніх послуг і дотриманням освітніх нормативно-правових документів, а також подальше вдосконалення місцевих нормативно-правових актів з метою визначення завдань, правил, форм і механізмів взаємодії закладів освіти та органів місцевого самоврядування;

- забезпечення розвитку мережі закладів загальної середньої освіти, установлення обсягів їх фінансування, координація діяльності закладів освіти, їх науково-методичне забезпечення, зміцнення матеріальної бази, господарське обслуговування, соціальний захист дітей і педагогічних працівників, створення сприятливих умов для навчання й виховання;

- створення умов для реалізації рівних прав усіх дітей на освіту;

- забезпечення участі учнів у розробці стратегії регіонального й місцевого розвитку, діяльності інститутів громадянського суспільства на місцевому рівні (громадських організацій, місцевих осередків партій), у 
місцевих виборах і місцевих ініціативах; налагодження системи узгодження важливих рішень органів місцевого самоврядування у сфері молодіжної політики з учнівською молоддю;

- закладання в місцевому бюджеті статей витрат, спрямованих на фінансування суспільно-корисної діяльності школярів;

- розширення й удосконалення можливостей користування інформацією, інфраструктурою, що $є$ в розпорядженні органів місцевого самоврядування, їхніми інформаційними каналами, досвідом експертів органів самоврядування;

- реалізація спільних для шкіл і органів місцевого самоврядування програм і проєктів, джерелом фінансування яких є зовнішні ресурси;

- профілактика правопорушень і соціально небезпечних хвороб у дитячому й молодіжному середовищі, формування навичок здорового способу життя.

Видами громадянської участі школярів у взаємодії з органами місцевого самоврядування є: участь у демократичних інституціях (засіданнях комісій міської, селищної, сільської рад, висунення школярами ідей і пропозицій); участь у повсякденному житті (створення ради класу, добровільне виконання різних доручень, завдань та зобов'язань у класі, школі, сім'ї); участь у соціальних проєктах (за потребами місцевої громади); ситуативна участь (участь у одноразових, конкретних подіях, як-то: зустріч із політиками, консультації 3 представниками органів місцевого самоврядування, акції та демонстрації з питань молодіжної політики); відкриті форми участі (регулярні збори учнів закладу освіти, мікрорайону або міста, що спрямовані на обговорення нагальних питань і прийняття рішень за ними); репрезентативні форми участі (діяльність молодіжних парламентів, молодіжних рад при органах місцевого самоврядування, учнівських рад у закладах загальної середньої освіти) (Citizenship, 2005, с. 29-30).

Загалом, взаємодія закладу освіти й органів місцевого самоврядування може здійснюватися через такі форми та методи співпраці (Кривонос, 2019; Перелік, 2017; Citizenship, 2005, с. 35-36): відкриті дні, свята та ярмарки; відвідування дітьми органів місцевої влади; проведення шкільних виборів за зразком реальних виборів та ігор, які імітують роботу міських рад; збір коштів для підтримки соціальних проєктів; волонтерська робота (прибирання дитячих майданчиків, надання допомоги сиротам, безпритульним дітям, літнім людям); улаштування учнів на короткий термін на роботу з метою ознайомлення з реальним трудовим життям; акції, соціальні флеш-моби, військово-патріотичні заходи, охорона пам'ятників, екологічні та трудові патрулі. Кожен із цих заходів - певна суспільно корисна справа, яку виконують разом учні, педагоги, працівники органів місцевого самоврядування. Окрім того, для педагогічних працівників закладів освіти можуть влаштовуватися заходи теоретичної та науково-практичної 
спрямованості (семінари, конференції, симпозіуми, круглі столи тощо), здійснюватися розробка та видання методичної, соціально-психологічної, юридичної літератури.

Показниками якості взаємодії школи й органів місцевого самоврядування $є$ наявність зв'язків і міцних взаємин між закладом освіти та сім'ями учнів; усвідомлення шкільною спільнотою та місцевою громадою актуальності освітніх проблем; активна участь учнів, учителів, батьків і членів органів місцевого самоврядування в спільних заходах; залучення до справ громади всіх суб'єктів освітнього процесу; розширення партнерських зв'язків; публічна презентація перед громадськістю звіту про діяльність школи; відкрита суспільна оцінка професійних досягнень педагогічного колективу закладу освіти й адміністрації, прозорість і відкритість у оцінюванні громадськістю якості надання освітніх послуг закладами освіти; наявність дієвих механізмів суспільного контролю за діяльністю школи; задоволення випускників закладу освіти рівнем соціалізації та самореалізації.

Водночас, труднощами у взаємодії органів місцевого самоврядування й закладів загальної середньої освіти $\epsilon:$ недостатня правова база в галузі освіти; низька мотивація окремих суб'єктів взаємодії щодо вкладення власних ресурсів у розвиток освітньої галузі (Садова, 2016) і формальне ставлення до співпраці; недостатнє фінансування для реалізації різноманітних форм і методів взаємодії; потреба в удосконаленні механізмів і практики безпосередньої демократії з метою збільшення участі громадян у роботі органів місцевого самоврядування та освітній діяльності тощо.

Висновки та перспективи подальших наукових розвідок. Отже, взаємодія органів місцевого самоврядування та закладу загальної середньої освіти - це співпраця органів місцевого самоврядування й закладу освіти, школярів і педагогів шляхом координації діяльності, спрямованої на розв'язання спільних проблем, успішну реалізацію їхніх функцій і виконання поставлених завдань. Вона дозволяє легше досягати освітні цілі, регулювати та розв'язувати соціальні проблеми, формувати соціальну злагоду в громаді. Взаємодія органів місцевого самоврядування зі школою є одним із важливих векторів у процесі виховання, що здійснюється в різних напрямах (організаційна, навчально-виховна, наукова, видавнича діяльність, матеріально-технічне забезпечення закладу освіти тощо).

Дана робота не вичерпує всіх аспектів дослідження. Перспективним $\epsilon$ аналіз досвіду запровадження механізмів участі учнівської молоді в житті громади.

\section{ЛІТЕРАТУРА}

Андрощук, І. В. (2013). Взаємодія як педагогічна категорія. Педагогічний дискурс, 14, 15-19 (Androshchuk, I. V. (2013). Interaction as a pedagogical category. Pedagogical discourse, 14, 15-19). 
Антонюк, О. (2006). Менеджмент в освітянській сфері: концептуальні засади. Персонал, 10, 58-67. (Antoniuk, 0. (2006). Management in educational sphere: conceptual foundations. Personnel, 10, 58-67). Retrieved from: http://personal.in.ua/article.php?ida=381.

Вербицька, П.В. (2010). Теоретико-методичні основи громадянського виховання учнівської молоді у загальноосвітніх навчальних закладах (автореф. дис. ... докт. пед. наук: 13.00.07). Київ (Verbytska, P. V. (2010). Theoretical and methodological fundamentals of school youth civic upbringing in the secondary schools (PhD thesis abstract: 13.00.07). Kyiv).

Волкова, Н. В. (2014). Місцеве самоврядування як суб'єкт управління освітою: кластерний підхід. Дніпропетровськ: Дніпроп. держ. фін. акад. (Volkova, N. V. (2014). Local self-government as a subject of management of education: cluster approach. Dnipropetrovsk: Dnipropetrovsk State Financial Academy).

Грішко-Дунаєвська, В.А. (2015). Основні підходи до вивчення проблеми взаємодії в науково-психологічній літературі. Збірник наукових праць Національної академії державної прикордонної служби України. Серія: Психологічні науки, 1, 56-69 (Grishko-Dunaievska, V.A. (2015). Principal approaches for cooperation problem studying in scientific-psychological literature. Collection of scientific works of National Academy of State Border Guard Service. Series: Psychological sciences, 1, 56-69).

Гурковський, В.І. (2010). Актуальні проблеми державного управління наукою та освітою в контексті глобальної інтелектуалізації. Наукові записки Інституту законодавства ВРу, 3, 167-171 (Gurkovskyi, V. I. Actual problems of governance science and education in the context of the Global Intellectual. Scientific Papers of the Legislation Institute of the Verkhovna Rada of Ukraine, 3, 167-171).

Дворецька, Г. В. (2002). Соціологія. Київ: KHEУ (Dvoretska, G. V. (2002). Sociology. Kyiv: KNEU).

Зимняя, И. А. (1997). Педагогическая психология. Ростов-на-Дону: Феникс (Zimniayа, I. A. (1997). Pedagogical psychology. Rostov-on-Don: Phoenix).

Ковальчук, Л. (2005). Педагогічна взаємодія викладача і студентів під час використання нових інформаційних технологій навчання у процесі вивчення педагогічних дисциплін. Вісник Львівського університету. Серія педагогічна, 19 (2), 17-25 (Kovalchuk, L. (2005). Higher school instructor and students interaction during the information technologies usage in learning Pedagogy. Bulletin of Lviv University. Series pedagogical, 19 (2), 17-25).

Кожушко, С. (2013). Взаємодія як філософське й психологічне поняття. Освіта регіону: політологія, психологія, комунікації, 3, 261-267 (Kozhushko, S. (2013). Interaction as a philosophic and psychological concept. Education of the Region: Political Science, Psychology, Communications, 3, 261-267).

Компонент «Партнерство школи і місцевої громади». (2019). (Component "Partnership between school and local community"). Retrieved from: http://gash.ussf.kiev.ua/ru/content/ компонент-«партнерство-школи-і-місцевоїгромади».

Коротаева, Е.В. (2007). Педагогические взаимодействия и технологии. Москва: Academia (Korotaieva, Ye. V. (2007). Pedagogical interaction and technologies. Moscow : Academia).

Кривонос, О. (2019). Виховання громадянських якостей школярів у Новій українській школі. Педагогічні науки: теорія, історія, інноваційні технології, 7(91), 61-71 (Krivonos, O. (2019). Upbringing of schoolchildren's civic qualities in New Ukrainian school. Pedagogical Science: Theory, History, Innovative Technologies, 7(91), 61-71). 
Левчук, М.Г. (2008) Взаємодія органів місцевого самоврядування та громадських об'єдань в умовах децентралізації державно-управлінських послуг. Державне управління: теорія і практика, 1(7). (Levchuk, M. G. (2008). The local government and non-government organizations' interaction at the conditions of the governmental services' decentralization. Public Administration: Theory and Practise, 1(7). Retrieved from: http://academy.gov.ua/ej/ej7/doc_pdf/levchuk.pdf.

Муркович, Л. (2011). Особливості взаємодії органів місцевого самоврядування і територіальної громади. Державне управління та місцеве самоврядування, 3(10). (Murcovich, L. (2011). The peculiarities of co-operation of local selfgovernment organs and territorial commune. Public administration and local selfgovernment, 3(10)). Retrieved from: http://dridu.dp.ua/vidavnictvo/2011/2011_03(10)/11mlistg.pdf.

Перелік заходів і завдань Комплексної програми розвитку освіти в місті Марганці на 2018-2020 роки (2017). Марганець (List of activities and tasks of the Complex program of education development in Marganets for 2018-2020 (2017).

Полішкевич, Л. (2016). Теоретичні засади взаємодії органів місцевого самоврядування 3 громадськістю. Ефективність державного управління, 4(49), 282-289 (Polishkevych, L. (2016). Theoretical principles of interaction between local government bodies and the public. Efficiency of Public Administration, 4(49), 282-289).

Психология. Словарь (1990). А. В. Петровский, М. Г. Ярошевский (ред.). Москва : Политиздат (Psychology. Dictionary (1990). A. V. Petrovskiy, M. G. Yaroshevskiy (Ed.). M oscow : Politizdat).

Рашитова, Н.К. (2010). Проблеми впровадження державно-громадського управління освітою та шляхи їх розв'язання в Україні. Публічне адміністрування: теорія та практика, 1(3). (Rashitova, N. K. (2010). Problems of plantation education administration system and the ways how to solve it. Public Administration: Theory and Practise, 1(2)). Retrieved from: http://www.dridu.dp.ua/zbirnik/2010-01/10rnksru.pdf.

Садова, О.Г. (2016). Особливості застосування технології "партнерство у громаді" у практиці освітньої діяльності сільської школи. Таврійський вісник oсвimu, 1(53), 60-65 (Sadova, O.G. (2016). The peculiarities of usage of the technology "community partnership" in the practice of educational activity of a rural school. Taurian Herald of Education, 1(53), 60-65).

Співпраця школи, влади та громади- шлях до розбудови громадянського суспільства (2017р.): (не)конфреренція (Івано-Франківськ, 5 грудня 2017 р.). (Interaction of school, government and community is a way to development of civil society (2017): (non)conference (Ivano-Frankivsk, December 5, 2017)). Retrieved from: https://doccu.in.ua/rozbudovuiemo-hromadianske-suspilst/.

Теорія управління в органах внутрішніх справ (2007). В. А. Ліпкан (ред.). Київ: КНТ (Theory of management in internal affairs bodies (2007). V. A. Lipkan (Ed.). Kyiv: KNT).

Ярмак, О.М. (2006). Поняття, сутність взаємодії та ії роль у розвитку соціальної системи. Право і безпека, 5, 46-49 (Yarmak, O. М. (2006). Concept, essence of interaction and its role in development of social system. Law and security, 5, 46-49).

Citizenship education at school in Europe (2005). Brussels: Eurydice. Retrieved from: http://www.indire.it/lucabas/lkmw_file/eurydice/Citizenship_schools_Europe_2005 _EN.pdf. 


\section{PEЗЮМE}

Жадько Елена. Организация взаимодействия учреждений общего среднего образования и органов местного самоуправления в образовании и воспитании детей.

В статье на основе анализа научной литературы и периодических изданий определена сущность понятия взаимодействия органов местного самоуправления и учреждения общего среднего образования (сотрудничество органов местного самоуправления и образовательного учреждения, школьников и педагогов путем координации деятельности, направленной на решение общих проблем, успешную реализацию их функций и выполнение задач) и роль местного самоуправления во взаимодействии с образовательными учреждениями. На основе наблюдений, обобщения опыта взаимодействия органов местного самоуправления и образовательных заведений раскрыты направления их общей деятельности.

Ключевые слова: взаимодействие, органы местного самоуправления, учреждение общего среднего образования, воспитание, образование, дети, организация, направления.

\section{SUMMARY}

Zhacko Olena Organization of interaction of general secondary education institutions and local self-government bodies in children's upbringing and education.

Based on the analysis of scientific literature and periodicals, the author has defined the essence of the concept of interaction of local self-government bodies and general secondary education institutions. It means cooperation of local self-government bodies and general secondary education institutions, schoolchildren and teachers due to coordination of activities aimed at solving common problems, successful implementation of their functions and performance of tasks. The role of local self-government in interaction with education institutions has been determined. Based on the observations and generalization of experience of interaction of local self-government bodies and education institutions, the directions of their common activities have been determined. They include: control over compliance with regulatory documents by education institutions; promoting implementation of state education policy; monitoring of scientific-technical and innovative activities of education institutions; their scientific-methodological and financial-technical support; formation of regional scientific policy; promoting development of intellectual, educational, scientific and technical potential of people; creating conditions for realization of all children's equal rights to education; financing of schoolchildren's socially useful activities; ensuring schoolchildren's involvement in development of strategies of regional and local development; ensuring development of a network of general secondary education institutions, social protection of schoolchildren and pedagogical staff, creation of favorable conditions for children's education and up-bringing; implementation of programs and projects common to schools and local governments; prevention of crimes and socially dangerous diseases in children and youth, formation of their healthy lifestyle skills; ensuring children's participation in various activities of social institutions at the local level, in local elections and different local initiatives; providing joint activities with central public authorities and cooperation at the international level; expansion and improvement of opportunities to use the infrastructure, information and experience of the experts of local self-government by education institutions, etc. The analysis of implementation of the mechanism of schoolchildren's participation in life of their community is considered to be a perspective for further research.

Key words interaction, local self-government bodies, general secondary education institutions, upbringing, education, children, organization, directions. 